\title{
DICOMA ANOMALA SOND.: A REVIEW OF ITS BOTANY, ETHNOMEDICINE, PHYTOCHEMISTRY AND PHARMACOLOGY
}

\author{
ALFRED MAROYI* \\ Department of Botany, Medicinal Plants and Economic Development Research Centre, University of Fort Hare, Private Bag X1314, \\ Alice 5700, South Africa. Email: amaroyi@ufh.ac.za
}

Received: 28 February 2018, Revised and Accepted: 20 March 2018

\begin{abstract}
Dicoma anomala is used as herbal medicine to treat and manage fever, coughs, colds, sore throats, abdominal pain, diarrhea, dysentery, constipation, intestinal worms, and sexually transmitted infections in tropical Africa. The aim of this study was to summarize the research that has been done on the ethnomedicinal uses, phytochemistry, and pharmacological properties of $D$. anomala in tropical Africa. The literature search for information on ethnomedicinal uses and pharmacological activities of D. anomala was undertaken using databases such as Web of Science, Scopus, Google Scholar, Science Direct, BioMed Central, PubMed, and Springer link. Other relevant literature sources included books, book chapters, websites, theses, conference papers, and other scientific publications. This study showed that D. anomala is used as herbal medicine in $57.1 \%$ of the countries in tropical Africa where it is indigenous. The species is used to treat 66 and five human and animal diseases, respectively. Several classes of secondary metabolites including acetylenic compounds, diterpene, flavonoids, phenols, phytosterols, saponins, sesquiterpenes, tannins and triterpenes have been isolated from D. anomala. Different aqueous and organic extracts of D. anomala exhibited anthelmintic, anticancer, antihyperglycemic, anti-inflammatory, antimicrobial, antioxidant, antiplasmodial, and hepatoprotective activities. The documented information on the botany, ethnomedicinal uses, phytochemistry, and pharmacological properties of D. anomala provide baseline data required for further ethnopharmacological studies on the species.
\end{abstract}

Keywords: Dicoma anomala, Ethnopharmacology, Primary health care, Traditional medicine, Tropical Africa.

(C) 2018 The Authors. Published by Innovare Academic Sciences Pvt Ltd. This is an open access article under the CC BY license (http://creativecommons. org/licenses/by/4. 0/) DOI: http://dx.doi.org/10.22159/ajpcr.2018.v11i6.25538

\section{INTRODUCTION}

Dicoma anomala Sond. is traditionally used as herbal medicine in tropical Africa [1,2]. According to Van Wyk [3], D. anomala leaves and roots have commercial potential as remedies for colds, fever, stomach complaints, and as general herbal medicine. Research by Jacot-Guillarmod [4] and Moteetee and Van Wyk [5] showed that D. anomala is an important medicinal plant in the Materia medica of Lesotho where it is used for most common and everyday ailments, namely, respiratory and digestive problems. In South Africa and Zimbabwe, the species is regarded as a panacea, that is, remedy for all diseases [6,7]. Fresh and dry root or root decoction and tinctures are taken orally to treat fever, coughs, colds, sore throats, abdominal pain, diarrhea, dysentery, constipation, and intestinal worms [6-8]. D. anomala is also used to treat gonorrhea and other venereal diseases and as purgative in the treatment of hemorrhoids [7]. Roots of D. anomala are sold in informal herbal medicine "muthi" markets in Malawi [9,10], Gauteng [11], and the Northern Cape [12] provinces in South Africa. Therefore, D. anomala is widely collected from the wild as herbal medicine or the species is collected for sale in herbal "muthi" markets. Due to overexploitation as herbal medicine, D. anomala is categorized as vulnerable (VU A2d) in Lesotho [13] based on the IUCN Red List Categories and Criteria version 3.1 of threatened species (http://www.iucnredlist.org). Talukdar [13] argued that there has been a decline in the population of D. anomala in Lesotho due to habitat loss and excessive harvesting of the species for traditional medicine. The present review is, therefore, aimed at documenting the ethnomedicinal uses, biological activities, and the correlated chemical compounds of D. anomala with emphasis on the validation of the ethnomedicinal uses of the species. Results of this review are expected to reveal research challenges and perspectives required to address the knowledge gaps of this important medicinal plant species in tropical Africa.

\section{BOTANICAL DESCRIPTION, OCCURRENCE, AND DISTRIBUTION}

The genus Dicoma Cass. (Family: Asteraceae) was first described by Cassini in 1817, comprise 50 species and 16 of these occur in southern Africa [14-21]. The genus name Dicoma was derived from Greek words "di" meaning two and "kome" meaning tuft of hair, in reference to the double row of pappus bristles which are characteristic of the species. The species name "anomala" is Latin, meaning irregular or deviating from the normal [22]. D. anomala is a highly variable species, research by Ortiz and RodriquezOubiña [23] showed that the speciesis a single complex species characterized by three distinct subspecies namely $D$. anomala Sond. subsp. anomala, occurring throughout most of the species' range, D. anomala Sond. subsp. attenuata (S. Moore) Ortiz and RodriquezOubiña, which is restricted to eastern central Angola, the Democratic Republic of Congo and Zambia, and D. anomala Sond. subsp. gerrardii (Harv. ex F.C. Wilson) Ortiz and Rodriquez-Oubiña. Most published literature, ethnobotany researchers, traditional healers, and local communities do not separate $D$. anomala into specific subspecies, but D. anomala sensual to is recognized, and the same approach has been adopted in this study.

D. anomala has been recorded in Angola, Botswana, Burundi, Democratic Republic of Congo, Lesotho, Malawi, Mozambique, Rwanda, South Africa, Tanzania, Uganda, Zambia and Zimbabwe [14-21]. D. anomala occurs in stony grasslands, hillsides or flat grassland and in savanna on doleritic or sandy soils at altitudes ranging from 165 to $2075 \mathrm{~m} \mathrm{[22].} \mathrm{D.} \mathrm{anomala} \mathrm{is} \mathrm{an} \mathrm{erect,} \mathrm{suberect} \mathrm{or} \mathrm{prostrate,} \mathrm{decumbent,}$ and perennial herb-bearing aromatic semi-woody tubers at the base of a woody subterranean stem. It may have few to many hairy, erect stems arising from a woody rootstock. The stems range from 5 to $60 \mathrm{~cm}$ long, are branched, yellowish, trail along the ground and over surrounding plants and rocks [16]. The leaves are simple, narrow, positioned alternately on the stem, stalkless, linear or narrowly lanceolate in shape. The upper surface of the leaves is glabrous, olive green, sometimes grey, rough, with a prominent central vein along which the leaf folds inward. The lower surface is white and hairy with a faintly uneven margin. Flower heads are terminal, cup or cone-shaped, cream to pinkish-white in color. 


\section{ETHNOMEDICINAL USES OF D. ANOMALA}

The roots of $D$. anomala are widely used to cure at least 66 and five human and animal diseases and ailments, respectively, in Africa (Table 1). Ethnomedicinal information has been found in Botswana, Lesotho, Malawi, Namibia, South Africa, Swaziland, Tanzania, and Zimbabwe, representing $57.1 \%$ of the countries where D. amomala is indigenous. The country with the highest number of ethnomedicinal uses is South Africa with 37 records of human ailments treated or managed by concoctions prepared from $D$. anomala, based on 16 literature records (Fig. 1). Lesotho has 32 ethnomedicinal uses with 13 literature records, followed by Zimbabwe with 23 uses and eight literature records, Malawi with 13 uses and three literature records and Namibia with nine uses and single records (Fig. 1). Gastrointestinal disorders such as diarrhea, dysentery and stomach problems, pain, sores and wounds, colds, cough and sore throat, sexually transmitted infections (STIs), blood circulation problems, fever, malaria, and ethnoveterinary medicine (Table 2) are the most commonly treated human and animal ailments and diseases using concoctions prepared from $D$. anomala.

Apart from momotherapeutic preparations, D. anomala is also used in combination with other plant species, for example, in Lesotho, the root infusions of D. anomala are taken orally mixed with roots of Berkheya setifera DC. as remedy for bilious attacks [8]. The root infusion of the species are also taken orally mixed with Scabiosa columbaria L. for painful menstruation $[4,5,40]$. The root infusion of the species is also taken orally mixed with Helichrysum caespititium (DC.) Sond. ex Harv., S. columbaria and Zantedeschia albomaculata (Hook.) Baill. for venereal diseases $[8,33]$. The root infusion of the species is also given to livestock mixed with Cymbopogon spp. as remedy for gall sickness [4,5,40]. In Malawi, root infusion of $D$. anomala is taken orally mixed with roots of Trichodesma physaloides (Fenzl) A.DC. as remedy for backache [6]. In Malawi and Zimbabwe, root infusion of D. anomala is taken orally mixed with soot and roots of Aspilia pluriseta Schweinf. to initiate labour, ensure easy childbirth, and facilitate the expulsion of placenta and clearing of the womb after birth in both women [6].

\section{PHYTOCHEMISTRY}

Phytochemical investigations of $D$. anomala have identified several classes of secondary metabolites; including acetylenic compounds, diterpene, flavonoids, phenolic acids, phytosterols, saponins, sesquiterpene lactones, tannins and triterpenes [63-68]. This is typical of Asteraceae taxa which are known to synthesize secondary metabolites such as flavonoids, polyacetylenes, and terpenoids [69]. The aerial parts of $D$. anomala yielded acetylenic compounds, namely, stigmasterol, $\beta$-sitosterol, lupeol and some sesquiterpene lactones [63,70]. The sesquiterpene lactones included germacranolides, with a 7,8-lactone function, albicolide and 14-acetoxydicomanolide, with 6,7-lactone closure [63]. Bohlmann et al. [64] isolated germacrene D, lupeol, taraxasterol and sesquiterpene lactones from aerial parts of $D$. anomala. The roots of $D$. anomala yielded sitosterols, lupenone, guaianolides and eudesmanolides [64]. Investigation of the aerial parts of $D$. anomala collected in Namibia yielded melampolides, germacranolides and a lactone, in addition to the lupeol and taraxasterol and their acetates, and two flavonoids, cirsimaritin and scutellarein [65]. Van der Merwe [66] isolated (3aS,5aS,9aR,9bS)-5a methyl-3,9-dimethylidene-4,5,9a,9b-tetrahydro-3aHnaphtho[7,8-d] furan-2,8-dione from $D$. anomala roots. Marekerah [26] isolated alkaloids, glycosides, saponins, sterols, and reducing sugars from acetone root extracts of $D$. anomala. Rademeyer et al. [67] isolated a dehydrobrachylaenolide, an eudesmane-type sesquiterpene lactone called 3-oxoeudesma-1,4(15),11 (13)-triene-12,6a-olide from D. anomala roots. Becker et al. [68] isolated a eudesmanolide-type sesquiterpene lactone, 3-oxoeudesma-1,4(15),11(13)-triene-12,6a-lide commonly called dehydrobrachylaenolide from the roots of $D$. anomala. Munodawafa et al. [71] isolated saponins and tannins from D. anomala roots.

\section{PHARMACOLOGICAL ACTIVITIES}

The following activities have been reported from $D$. anomala including anthelmintic [58,72], anticancer [66,70], antihyperglycemic [73,74], anti-inflammatory[47],antimicrobial[26,28,71,75-77],antioxidant[26,71,74,78,79], antiplasmodial [66,80], hepatoprotective $[56,79]$, toxicity, and cytotoxicity $[68,71,74,80,81]$.

\section{ANTHELMINTIC}

Ndamba et al. [58] evaluated in vivo antischistosomal activities of $D$. anomala root extracts by administering the extracts orally to hamsters infected with Schistosoma haematobium cercariae. The results obtained showed moderate activity with worm load of 201 and 1874 egg count in comparison with a single worm load and 137 egg count exhibited by the control, praziquantel [58]. Similarly, Mølgaard et al. [72] evaluated the anthelmintic effects of $D$. anomala root extracts against cysticercoids of the cestode Hymenolepis diminuta. The extracts killed the newly excysted cysticercoids within an hour, when incubated in a culture medium. The lethal concentrations of $D$. anomala extracts were $31.0 \mathrm{mg} / \mathrm{ml}$ after an hour and $1.0 \mathrm{mg} / \mathrm{ml}$ after $24 \mathrm{~h}$ [72]. These pharmacological evaluations are of importance in the traditional use of $D$. anomala against intestinal worms in Lesotho [8], Namibia [35], South Africa [8,34], and Tanzania [8], as herbal medicine against bilharzia in Zimbabwe [58] and future research focussing on control and management of schistosomiasis in tropical Africa.

\section{ANTICANCER}

Van der Merwe [66] evaluated in vitro anticancer activities of (3aS,5aS,9aR,9bS)-5amethyl-3,9-dimethylidene-4,5,9a,9b-tetrahydro-

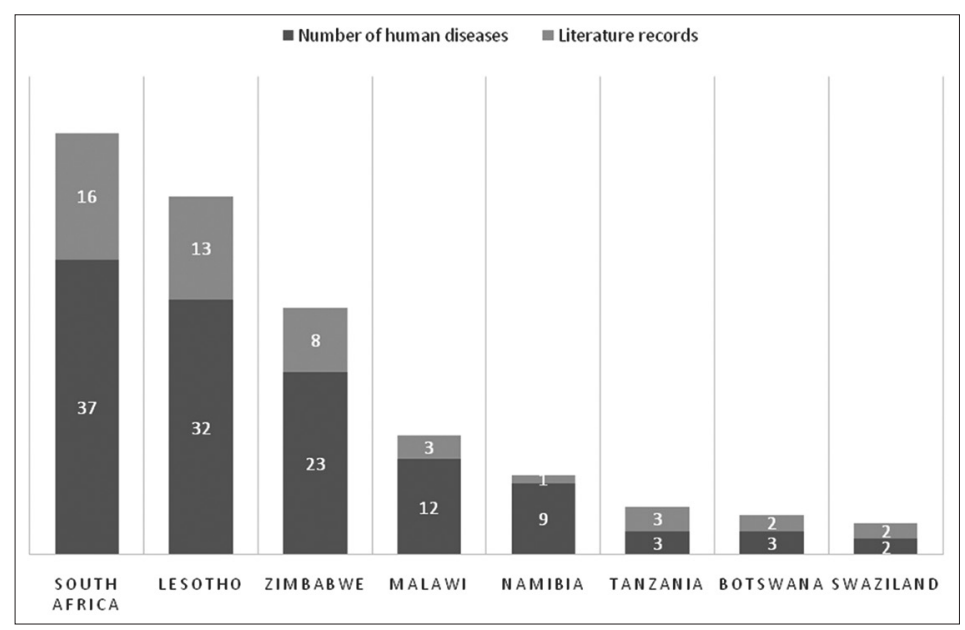

Fig. 1: Major diseases and ailments treated by Dicoma anomala in tropical Africa 
Table 1: Ethnomedicinal uses of $D$. anomala in tropical Africa

\begin{tabular}{|c|c|c|c|}
\hline Use & Plant parts used & Country practiced & References \\
\hline Abdominal pains & Root infusion taken orally & Zimbabwe & {$[6,24-26]$} \\
\hline Abortifacient & Root infusion taken orally & Malawi & [27] \\
\hline Acne & $\begin{array}{l}\text { Tuber used in combination with } \\
\text { E. elephantina (Burch.) Skeels }\end{array}$ & South Africa & [28-30] \\
\hline Antidote for any poison & Root decoction taken orally & South Africa, Zimbabwe & {$[6,26,31]$} \\
\hline Anti-emetic & Root infusion taken orally & Malawi & [6] \\
\hline Aphrodisiac & Root infusion taken orally & Malawi & [27] \\
\hline Backache & Root infusion taken orally & Lesotho & [5] \\
\hline Backache & $\begin{array}{l}\text { Root infusion taken orally mixed with } \\
\text { roots of T. physaloides (Fenzl) A.DC. }\end{array}$ & Malawi & [6] \\
\hline Bilious attacks & $\begin{array}{l}\text { Root infusions taken orally mixed with } \\
\text { roots of } B \text {. setifera DC. }\end{array}$ & Lesotho & {$[32]$} \\
\hline Bladder problems & Root decoction taken orally & South Africa & {$[12]$} \\
\hline $\begin{array}{l}\text { Bladder problems in } \\
\text { women }\end{array}$ & $\begin{array}{l}\text { Root infusion taken orally and root } \\
\text { burnt and smoke directed toward } \\
\text { pudendum }\end{array}$ & Zimbabwe & {$[6]$} \\
\hline $\begin{array}{l}\text { Blood circulation } \\
\text { diseases }\end{array}$ & Root decoction taken orally & Namibia, South Africa & {$[8,34-36]$} \\
\hline $\mathrm{BC}$ & Leaf and root infusion taken orally & Lesotho & {$[37,38]$} \\
\hline $\begin{array}{l}\text { Cardiovascular } \\
\text { disorders }\end{array}$ & Root infusion taken orally & Namibia, South Africa & {$[34,35]$} \\
\hline Cataracts & Root infusion taken orally & Zimbabwe & {$[6]$} \\
\hline Chest pains & Root decoctions taken orally & Swaziland & [39] \\
\hline Colds & Root decoction taken orally & $\begin{array}{l}\text { Lesotho, Namibia, South Africa, } \\
\text { Zimbabwe }\end{array}$ & {$[4,8,12,24,34,35,40,41]$} \\
\hline $\begin{array}{l}\text { Constipation and } \\
\text { flatulency }\end{array}$ & Root infusions taken orally & Lesotho & {$[5,40]$} \\
\hline Cough & Bark, root decoction taken orally & $\begin{array}{l}\text { Botswana, Malawi, Namibia, South } \\
\text { Africa }\end{array}$ & {$[6,27,32-35,42,43]$} \\
\hline Dermatitis & Not stated & South Africa & {$[44]$} \\
\hline Diabetes & Leaf and root infusion taken orally & Lesotho, South Africa & {$[5,37,45]$} \\
\hline Diarrhea & Root decoction taken orally & $\begin{array}{l}\text { Botswana, Lesotho, Namibia, South } \\
\text { Africa, Zimbabwe }\end{array}$ & {$[4,5,8,26,40,41,46-49]$} \\
\hline Enema & Root decoction taken orally & South Africa & {$[12]$} \\
\hline Enemas & Root decoction taken orally & South Africa & [8] \\
\hline Fever & Root decoction taken orally & Lesotho, South Africa, Zimbabwe & {$[6,34,41]$} \\
\hline Genital problems & Root decoction taken orally & South Africa & [12] \\
\hline Gonorrhea & Root infusion taken orally & Zimbabwe & {$[6,26]$} \\
\hline Hemorrhoids & Root infusion taken orally & Namibia & {$[35]$} \\
\hline Headache & Root infusion taken orally & Malawi & [27] \\
\hline Heartburn & Root infusions taken orally & Lesotho & [5] \\
\hline HIV related infections & Leaf and root infusion taken orally & Lesotho & [37] \\
\hline $\begin{array}{l}\text { Indigestion during } \\
\text { pregnancy }\end{array}$ & Root infusion taken orally & South Africa & {$[31,51]$} \\
\hline Induce labor & Leaf, root infusion taken orally & Lesotho, Zimbabwe & {$[38,52]$} \\
\hline Induce labor & $\begin{array}{l}\text { Root infusion taken orally mixed with } \\
\text { soot and roots of } A \text {. pluriseta Schweinf. }\end{array}$ & Malawi, Zimbabwe & [6] \\
\hline Infertility & Leaf, root decoction taken orally & Lesotho, South Africa & {$[8,38,52,53]$} \\
\hline Intestinal parasites & Not stated & South Africa & {$[44]$} \\
\hline Intestinal worms & Root decoction taken orally & $\begin{array}{l}\text { Lesotho, Namibia, South Africa, } \\
\text { Tanzania }\end{array}$ & {$[8,34,35]$} \\
\hline Kidney problems & Root decoction taken orally & South Africa, Swaziland & {$[12,54]$} \\
\hline $\begin{array}{l}\text { Luck charm, protective } \\
\text { charm }\end{array}$ & $\begin{array}{l}\text { Tuber used as talisman and body } \\
\text { washed with infusion or a piece kept } \\
\text { under tongue }\end{array}$ & Malawi, Zimbabwe & {$[6,9,27,46,55]$} \\
\hline Madness & Body washed with root infusion & Zimbabwe & {$[6]$} \\
\hline Malaria & Root infusion taken orally & Zimbabwe & [26] \\
\hline Measles & Root decoction taken orally & South Africa & [36] \\
\hline Nasal congestion & Root powder used as snuff & Lesotho & [5] \\
\hline Pain & Root decoction taken orally & Lesotho, Zimbabwe & {$[6,41]$} \\
\hline Painful menstruation & Leaf, root infusion taken orally & Lesotho & [38] \\
\hline Painful menstruation & $\begin{array}{l}\text { Root infusion taken orally mixed with } \\
\text { S. columbaria L. }\end{array}$ & Lesotho & {$[4,5,40]$} \\
\hline Painful uterus & Root powder inserted into vagina & Zimbabwe & [6] \\
\hline
\end{tabular}


Table 1: (Continued)

\begin{tabular}{|c|c|c|c|}
\hline Use & Plant parts used & Country practiced & References \\
\hline Pneumonia & Root infusion taken orally & South Africa, Zimbabwe & {$[6,7]$} \\
\hline Prostrate problems & Root decoction taken orally & South Africa & [12] \\
\hline Purgatives & Root decoction taken orally & Lesotho, South Africa & {$[8,34]$} \\
\hline Respiratory complaints & Root decoction taken orally & South Africa & [42] \\
\hline Rheumatism & Root decoction taken orally & Lesotho, Malawi & {$[27,41]$} \\
\hline Ringworm & Root powder used as ointment & Lesotho, South Africa & {$[30,34,56,57]$} \\
\hline Schistosomiasis & Root decoction taken orally & Zimbabwe & [58] \\
\hline Skin sores & Root ointment applied on skin & Lesotho, Zimbabwe & {$[26,57]$} \\
\hline Sore throat & Root infusion taken orally & Malawi, Zimbabwe & {$[6,27]$} \\
\hline STIs & Root decoction taken orally & South Africa & {$[36]$} \\
\hline Stomach problems & Leaf and root decoction taken orally & $\begin{array}{l}\text { Botswana, Lesotho, Malawi, South } \\
\text { Africa, Tanzania, Zimbabwe }\end{array}$ & {$[4,26,27,34,37,43,47,48,59,60]$} \\
\hline Swollen legs & Root decoction taken orally & South Africa & {$[36]$} \\
\hline Syphilis & Roots & Zimbabwe & [26] \\
\hline Toothache & Root decoction taken orally & Lesotho & {$[4,8,40]$} \\
\hline ТВ & Leaf and root infusion taken orally & Lesotho & [37] \\
\hline TB & $\begin{array}{l}\text { Tuber infusion taken orally mixed with } \\
\text { O. sphaerocarpa R. Fern and A. Fern. } \\
\text { bark }\end{array}$ & South Africa & [32] \\
\hline Ulcer & Not stated & South Africa & {$[44]$} \\
\hline Uterine disorder & Leaf, root infusion taken orally & Lesotho & [38] \\
\hline Venereal diseases & $\begin{array}{l}\text { Root infusion taken orally mixed } \\
\text { with H. caespititium (DC.) Sond. } \\
\text { ex Harv., S. columbaria and } \\
\text { Z. albomaculata (Hook.) Baill. }\end{array}$ & Lesotho & {$[5,32]$} \\
\hline Venereal diseases & Root infusion taken orally & South Africa & [34] \\
\hline Vermifuge & Root infusion taken orally & Lesotho & [5] \\
\hline Uterine disorder & Leaf and root infusion taken orally & Lesotho & [37] \\
\hline Wasting in infants & Root decoction taken orally & Zimbabwe & [26] \\
\hline Whooping cough & $\begin{array}{l}\text { Tuber infusion taken orally mixed with } \\
\text { O. sphaerocarpa R. Fern and A. Fern. } \\
\text { bark }\end{array}$ & South Africa & {$[32]$} \\
\hline Wounds and sores & $\begin{array}{l}\text { Flower, root powder mixed with fat } \\
\text { used as ointment }\end{array}$ & Lesotho, Malawi, South Africa & {$[4,5,8,27,30,34,40,47,56,57]$} \\
\hline \multicolumn{4}{|l|}{$\begin{array}{l}\text { Ethnoveterinary } \\
\text { medicine }\end{array}$} \\
\hline $\begin{array}{l}\text { Intestinal worm } \\
\text { infestations }\end{array}$ & Root decoction & South Africa & [8] \\
\hline Gall sickness & $\begin{array}{l}\text { Root infusion taken mixed with } \\
\text { Cymbopogon spp. }\end{array}$ & Lesotho & {$[4,5,40]$} \\
\hline Gall sickness & Leaf and root infusion taken orally & Lesotho, South Africa & {$[8,37]$} \\
\hline Wounds and sores & Root decoction & Lesotho & [8] \\
\hline Sterility in animals & Root decoction & Lesotho, South Africa & [8] \\
\hline
\end{tabular}

D. anomala: Dicoma anomala, O. sphaerocarpa: Ozoroa sphaerocarpa, H. caespititium: Helichrysum caespititium, S. columbaria: Scabiosa columbaria, Z.

albomaculata: Zantedeschia albomaculata, A. pluriseta: Aspilia pluriseta, B. setifera: Berkheya setifera, T. physaloides, Trichodesma physaloides, E. elephantina,

Elephantorrhiza elephantina, BC: Breast cancer, TB: Tuberculosis

Table 2: Major disease or ailment categories reported

\begin{tabular}{ll}
\hline Disease or ailment category & Number of literature reports \\
\hline Gastrointestinal disorders & 24 \\
Pain, sores and wounds & 19 \\
Colds, cough and sore throat & 15 \\
STIs & 7 \\
Blood circulation problems & 5 \\
Fever and malaria & 5 \\
Ethnoveterinary medicine & 5 \\
\hline
\end{tabular}

STIs: Sexually transmitted infections

3aHnaphtho[7,8-d]furan-2,8-dione isolated from D. anomala and root extract against the panels of human cancer cell lines such as leukaemia (L) lines, non-small cell lung cancer lines, colon cancer lines, central nervous system cancer lines, melanoma (M) lines, ovarian cancer lines, renal cancer lines, prostate cancer lines, and breast cancer (BC) lines. The compound showed $\mathrm{GI}_{50}$ value of $0.67 \mu \mathrm{g} / \mathrm{ml}$ [66]. Similarly, Mukanganyama et al. [70] evaluated the inhibition of human recombinant GSTP1-1 by sesquiterpene lactone isolated from D. anomala. The compound was found to be a potent GST P1-1 inhibitor showing $75 \%$ and $84 \%$ inhibition at $33 \mu \mathrm{M}$ and $100 \mu \mathrm{M}$, respectively. These findings serve as a scientific validation for the use of D. anomala against BC in Lesotho $[37,38]$.

\section{ANTIHYPERGLYCAEMIC}

Balogun and Ashafa [73] evaluated the antidiabetic activities of water, ethanol, hydroethanol, and methanol root extracts of $D$. anomala using the in vitro inhibition of $\alpha$-amylase and $\alpha$-glucosidase as well as against streptozotocin (STZ)-induced diabetic Wistar rats. The effect of administration of extract at 125, 250, and $500 \mathrm{mg} / \mathrm{kg}$ bodyweight on water consumption, feed intake, body-weight, blood 
glucose, carbohydrate-metabolizing enzymes, antioxidant enzymes, glycosylated hemoglobin, and lipid profiles was determined in STZ ( $60 \mathrm{mg} / \mathrm{kg}$ body weight)-induced diabetic rats with comparison to glibenclamide, $5 \mathrm{mg} / \mathrm{kg}$ body weight. All extracts showed activity against $\alpha$-amylase and $\alpha$-glucosidase, but water extract revealed the most effective inhibition with an $\mathrm{IC}_{50}$ value of 51.90 and $27.41 \mu \mathrm{g} / \mathrm{ml}$, respectively. The extract reversed toward normal control the elevated food or water intake, blood glucose levels, lipid peroxidation, lipid profiles, glycosylated hemoglobin and activities of gluconeogenesis enzymes with a concomitant decrease in body-weight, activities of enzymatic antioxidants, glycolytic enzymes as well as the high density lipoprotein-cholesterol level brought-about by STZ administration. Balogun and Ashafa [74] evaluated the antidiabetic activities of flavonoids isolated from the root extract of $D$. anomala using the inhibition of $\alpha$-AML and $\alpha$-GCD sucrase and maltase activities. Balogun and Ashafa [74] also evaluated the kinetic activities of flavonoids isolated from the root extract of $D$. anomala using the carbohydrate digestive enzymes including, alpha-glucosidase, sucrose, and maltase. The kinetics of mode of inhibition of alpha-amylase, alpha-glucosidase, sucrase, and maltase by flavonoids extract of $D$. anomala revealed an uncompetitive, non-competitive, competitive and non-competitive inhibition, respectively. These findings corroborate the traditional usage of the species as herbal medicine for diabetes in Lesotho and South Africa $[5,37,45]$.

\section{ANTI-INFLAMMATORY}

Shale et al. [47] evaluated anti-inflammatory activities of hexane, methanol and water leaf and root extracts of $D$. anomala using the cyclo-oxygenase bioassay. Hexane leaf extracts showed anti-inflammatory activity above $85 \%$ while hexane root extract showed activity of $79 \%$ which was not significantly different $(p<0.05)$ from activity of $87 \%$ displayed by the control, indomethacin [47]. These results support the traditional use of $D$. anomala in various inflammatory ailments and diseases such as sores, wounds, microbial infections, and injuries that result in cell damage and death.

\section{ANTIMICROBIAL}

Vlietinck et al. [75] evaluated antimicrobial activities of root extracts of D. anomala against Candida albicans, Escherichia coli, Microsporum canis, Pseudomonas aeruginosa, Staphylococcus aureus, and Trichophyton mentagrophytes using agar diffusion and agar dilution methods with neomycin and nystatin as controls. The extract showed activities against M. canis, S. aureus, and T. mentagrophytes. Vlietinck et al. [75] also evaluated antiviral activities of root extracts of $D$. anomala against poliomyelitis, coxsackie, semliki forest, herpes simplex and measles using the $50 \%$ endpoint titration technique. The root extract also showed antiviral properties, that is a reduction factor of the viral titer of 10 against poliomyelitis and weak activity against coxsackie, semliki forest, herpes simplex, and measles viruses.

Steenkamp et al. [76] evaluated antibacterial activities of D. anomala root aqueous and methanol extracts against E. coli, P. aeruginosa, S. aureus, and Streptococcus pyogenes using the micro-well dilution method with phenol as positive control. All D. anomala extracts showed the minimum inhibition concentration (MIC) values $>4 \mathrm{mg} / \mathrm{ml}$ against all the selected bacteria [76]. Munodawafa et al. [71] evaluated the antimicrobial activities of $D$. anomala methanol root extracts against Aspergillus niger, C. albicans, E. coli, P. aeruginosa, S. aureus, and Staphylococcus Group A using the agar well-diffusion method. The extracts showed activity against $S$. aureus and Staphylococcus Group A with $3.25 \pm 0.5 \mathrm{~mm}$ and $4.25 \pm 0.5 \mathrm{~mm}$ zones of imbibition, respectively. The MIC values for $S$. aureus and Staphylococcus Group A were $>10.0 \mathrm{mg} / \mathrm{ml}$ and $2.5 \mathrm{mg} / \mathrm{ml}$, respectively [71]. The extract also showed some activity against $C$. albicans with $5.5 \pm 0.58 \mathrm{~mm}$ zone of imbibition and the MIC value of $1.25 \mathrm{mg} / \mathrm{ml}$ [71].

Mabona et al. [28] and Mabona [77] evaluated the antimicrobial activities of aqueous and dichlomethane/methanol (1:1) tuber extracts of $D$. anomala using the micro-titer plate dilution technique against dermatologically relevant pathogens such as Brevibacillus agri, C. albicans, M. canis, Propionibacterium acnes, P. aeruginosa, S. aureus, Staphylococcus epidermidis, and T. mentagrophytes with ciprofloxacin and Amphotericin B as positive controls and acetone and dimethyl sulfoxide as negative controls. Mabona et al. [28] and Mabona [77] found varied antimicrobial activities of the aqueous and dichlomethane/methanol $(1: 1)$ tuber extracts with MIC values ranging from $0.03 \mathrm{mg} / \mathrm{ml}$ to $16.00 \mathrm{mg} / \mathrm{ml}$.

Marekerah [26] evaluated the antimicrobial activities of D. anomala acetone, chloroform, and petroleum ether root extracts against high vaginal swab, that is, a combination of different bacteria and fungi such as E. coli, Klebsiella spp., Proteus spp., and S. aureus [26] with ciprofloxacin as control. Antimicrobial activities of $D$. anomala extracts of $5 \mathrm{mg} / \mathrm{ml}$ represented by zones of imbibition ranged between 8.67 and $12.67 \mathrm{~mm}$ and for the $1 \mathrm{mg} / \mathrm{ml}$ extract, the range was $6.67-8.67 \mathrm{~mm}$. Acetone and chloroform extracts showed MIC values of $0.8 \mathrm{mg} / \mathrm{ml}$ while MIC value of petroleum ether extract was $0.9 \mathrm{mg} / \mathrm{ml}$ against the MIC value of 0.125 displayed by the control, ciprofloxacin [26]. These findings give some validation for the traditional use of $D$. anomala for treating acne vulgaris, skin infections, STIs, gastrointestinal disorders, sores, wounds, and other microbial infections.

\section{ANTIOXIDANT}

D. anomala showed antioxidant activities of $50 \%$ with $\mathrm{LC}_{50}$ value of $3000 \mu \mathrm{g} / \mathrm{ml}$ demonstrating high safety margins [71]. Balogun and Ashafa [78] evaluated the in vitro antioxidant activities of $D$. anomala ethanol and methanol root extracts using the 1,1-diphenyl-2picrylhydrazyl (DPPH), 2,2-azino-bis(3-ethylbenzothiazoline-6sulphonic acid (ABTS), hydroxyl and superoxide anion scavenging abilities as well as metal chelating and reducing power of the extracts. D. anomala ethanol extract exhibited some activity with $\mathrm{IC}_{50}$ value of $0.77 \mu \mathrm{g} / \mathrm{ml}$ for the nitric oxide scavenging and methanol extract with $\mathrm{IC}_{50}$ value of $3.50 \mu \mathrm{g} / \mathrm{ml}$ for metal chelating. Marekerah [26] evaluated the antioxidant activities of $D$. anomala acetone, chloroform, and petroleum ether root extracts using the phosphomolybdate assay. The acetone crude extract of $D$. anomala gave $3.49 \mu \mathrm{g}$ ascorbic acid equivalence (AAE) $/ 10 \mu \mathrm{g}$, chloroform displayed $2.89 \mu \mathrm{g} \mathrm{AAE} / 10 \mu \mathrm{g}$, while petroleum ether had least antioxidant activity with $0.95 \mu \mathrm{g}$ $\mathrm{AAE} / 10 \mu \mathrm{g}$ [26]. Balogun and Ashafa [79] evaluated the antioxidant activities of $D$. anomala aqueous, ethanol, hydroethanol and methanol root extracts using DPPH, nitric oxide, metal, chelating, ABTS, superoxide anion, and hydroxyl radicals assays. The aqueous extract exhibited the best activities with $\mathrm{IC}_{50}$ value of $15.20 \pm 0.03 \mu \mathrm{g} / \mathrm{ml}$, $11.70 \pm 0.10 \mu \mathrm{g} / \mathrm{ml}$, and $0.84 \pm 0.05 \mu \mathrm{g} / \mathrm{ml}$ in vitro in $\mathrm{DPPH}$, hydroxyl, and superoxide anion radicals, respectively, when compared with the standard. For the nitric oxide and ABTS inhibitions, best effects were exhibited by ethanolic and hydroethanolic extracts with $\mathrm{IC}_{50}$ value of $0.77 \pm 0.07 \mu \mathrm{g} / \mathrm{ml}$ and $0.60 \pm 0.02 \mu \mathrm{g} / \mathrm{ml}$, respectively [79]. The hydroethanolic extract had the highest amount of total antioxidant of $213.40 \pm 0.99 \mathrm{mg}$ gallic acid equivalents $(\mathrm{GAE}) / 100 \mathrm{~g}$ and total phenolic contents of $426.80 \pm 0.73 \mathrm{mg} \mathrm{GAE} / 100 \mathrm{~g}$, while the highest amount of flavonoids was found in the ethanolic extract amounting to $61.24 \pm 0.23 \mathrm{mg}$ QUE$/ 100 \mathrm{~g}$ [79]. Balogun and Ashafa [74] evaluated the free radical scavenging activities of flavonoids isolated from the root extract of $D$. anomala using DPPH, ABTS, hydroxyl radical, nitric oxide scavenging, metal chelating, and reducing power activities. The best antioxidant activity was demonstrated in ABTS and nitric oxide having $\mathrm{IC}_{50}$ values ranging from $386.90 \pm 4.91 \mu \mathrm{g} / \mathrm{ml}$ to $736.00 \pm 38.12 \mu \mathrm{g} / \mathrm{m}$, which was comparable to the $\mathrm{IC}_{50}$ values of $522.20 \pm 12.38 \mu \mathrm{g} / \mathrm{ml}$ to $1075.00 \pm 29.35 \mu \mathrm{g} / \mathrm{ml}$ demonstrated by the standard, quercetin. Therefore, the antioxidant activities demonstrated by the root extracts are probably due to the presence of flavonoids.

\section{ANTIPLASMODIAL}

Tselanyane [80] evaluated antiplasmodial activities of aqueous, chloroform, hexane, ethyl acetate, petroleum ether and methanol leaf, 
root and twig extracts of D. anomala against Plasmodium falciparum, a chloroquine-sensitive strain (D10) and chloroquine-resistant strains (RSA11, K1, and FAC8) using the parasite lactate dehydrogenase $(\mathrm{pLDH})$ assay. The extracts showed activity ranging from $\mathrm{IC}_{50}$ values of $0.42 \pm 0.04 \mu \mathrm{g} / \mathrm{ml}$ to $>100 \mu \mathrm{g} / \mathrm{ml}$ [80]. Van der Merwe [66] evaluated the antiplasmodial activities of ethanol root extract of $D$. anomala against chloroquine-sensitive D10 and choroquine-resistant strain K1 P. falciparum using the $\mathrm{pLDH}$ assay. The ethanol extract exhibited an IC of $1.4 \mu \mathrm{g} / \mathrm{ml}$ [66]. Becker et al. [68] evaluated in vitro antiplasmodial activities of 3-oxoeudesma-1,4(15),11(13)-triene-12,6a-lide isolated from $D$. anomala against chloroquine-sensitive D10 strain and chloroquine-resistant $\mathrm{K} 1$ strain $P$. falciparum using the pLDH assay. The compound showed an $\mathrm{IC}_{50}$ of $0.455 \mu \mathrm{g} / \mathrm{ml}$ against the chloroquinesensitive D10 strain and $1.0 \mu \mathrm{g} / \mathrm{ml}$ against the chloroquine-resistant $\mathrm{K} 1$ strain when tested in vitro [68]. Van der Merwe [66] evaluated in vitro antiplasmodial activities of the compound (3aS,5aS,9aR,9bS)5amethyl-3,9-dimethylidene-4,5,9a,9b-tetrahydro-3aHnaphtho[7,8-d] furan-2,8-dione isolated from $D$. anomala against chloroquine-sensitive D10 strain and chloroquine-resistant $\mathrm{K} 1$ strain P. falciparum using the pLDH assay. The compound showed an $\mathrm{IC}_{50}$ of $0.38 \mu \mathrm{g} / \mathrm{ml}$ against the chloroquine-sensitive D10 strain and $0.06 \mu \mathrm{g} / \mathrm{ml}$ against the chloroquine-resistant K1 strain when tested in vitro [66]. These results corroborate the traditional uses of $D$. anomala as remedy for fever and Malaria in Lesotho [41], South Africa [34], and Zimbabwe [6,26].

\section{HEPATOPROTECTIVE}

Balogun and Ashafa [56] evaluated the protective potentials of the aqueous root extract of $D$. anomala against isoproterenol-induced myocardial damage in Wistar rats. Various concentrations of 125, 250, and $500 \mathrm{mg} / \mathrm{kg}$ body weight of the extract and their effects on the rats' feed and water intake, body weight changes, serum enzymes, aspartate transaminase, alanine transaminase, creatinine phosphokinase, tissue antioxidant enzymes, including catalase, glutathione peroxidase, and lipid peroxidation were determined during a 30-day experimental period. Histopathological examination of isoproterenol-induced myocardial rats treated with the extract revealed evidence of oedema and myocardial necrosis at 125 and $250 \mathrm{mg} / \mathrm{kg}$ body weight doses; however, these alterations were ameliorated or cleared at $500 \mathrm{mg} / \mathrm{kg}$ dose, suggesting attainment of maximum efficacy. Similarly, Balogun and Ashafa [79] evaluated the hepatoprotective activities of D. anomala aqueous, ethanol, hydroethanol and methanol root extracts on body weight, feed and water intake, biochemical parameters and organ histology of Wistar rats during the 15 days study. Pre-treatment and treatment with different concentrations of $D$. anomala extracts significantly attenuated the elevated serum activities of aspartate, transaminase, alanine transaminase levels while increasing the activities of superoxide dismutase, catalase, and glutathione peroxidase. The histopathological evaluations revealed extensive liver damage characterized by severe vacuolar and cytoplasmic degeneration, hepatic necrosis, and cellular infiltration in pre-treated groups while in the treated groups; such liver damages were not observed most especially at $500 \mathrm{mg} / \mathrm{kg}$ dose [79]. These results showed the hepatoprotective potential of $D$. anomala aqueous root extracts against $\mathrm{CCl}_{4}$-induced oxidative stress and therefore, D. anomala extracts could play an important role in the management or treatment of cardiacrelated diseases.

\section{TOXICITY AND CYTOTOXICITY}

Tselanyane [80] evaluated in vitro cytotoxicity of aqueous, chloroform, hexane, ethyl acetate, petroleum ether and methanol leaf, root and twig extracts of $D$. anomala against a Chinese hamster ovary $(\mathrm{CHO})$ cell line usingthe3-(4,5-dimethylthiazol-2-yl)-2,5-diphenyltetrazoliumbromide (MTT) assay. The extracts showed some activity with $\mathrm{IC}_{50}$ values ranging from $0.44 \mu \mathrm{g} / \mathrm{ml}$ to $31.33 \mu \mathrm{g} / \mathrm{ml}$ [80]. Van der Merwe [66] evaluated in vitro cytotoxicity of the compound (3aS,5aS,9aR,9bS)-5amethyl3,9-dimethylidene-4,5,9a,9b-tetrahydro-3aHnaphtho[7,8-d]furan-2,8dione isolated from $D$. anomala against $\mathrm{CHO}$ cell line using the MTT assay. The compound showed IC ${ }_{50}$ value of $4.2 \mu \mathrm{g} / \mathrm{ml}$ [66]. Becker et al.
[68] evaluated in vitro cytotoxicity of D. anomala against CHO cell line using the MTT assay. Becker et al. [68] evaluated in vitro cytotoxicity of the compound 3-oxoeudesma-1,4(15),11(13)-triene-12,6a-lide isolated from $D$. anomala against ( $\mathrm{CHO}$ cell line using the MTT assay. The compound showed $\mathrm{IC}_{50}$ value of $17.2 \mu \mathrm{M}$ against $35.8 \mu \mathrm{M}$ displayed by chloroquine [68]. Asita et al. [81] evaluated the cytotoxicity, genotoxicity, and modulation of cyclophosphamide and ethyl methanesulfonate-induced genotoxicity of methanolic root extracts of D. anomala using the Allium cepa assay. The three concentrations $(0.0625 \mathrm{mg} / \mathrm{ml}, 0.125 \mathrm{mg} / \mathrm{ml}, 0.25 \mathrm{mg} / \mathrm{ml})$ of $D$. anomala tested were cytotoxic and genotoxic to the $A$. cepa root meristem cells. The mixture of cyclophosphamide at $1.25 \mathrm{mg} / \mathrm{ml}$ with each concentration of extract of $D$. anomala separately was cytotoxic and genotoxic to the root tip meristem cells of A. сера. The mixture of ethyl methane sulfonate at $0.25 \mathrm{mg} / \mathrm{ml}$ with each concentration of extract of $D$. anomala separately was genotoxic to the root tip meristem cells of $A$. cepa. These results suggest that the tested concentrations of root extracts of $D$. anomala exerted mitodepressive or cytotoxic effects on cell division of A. cepa root meristem cells [81]. Munodawafa et al. [82] evaluated toxicity of $D$. anomala tuber using the brine shrimp (Artemia salina) toxicity bioassay test with Nerium oleander as positive control. D. anomala extract showed $\mathrm{LC}_{50}$ value of $3040 \pm 1060 \mu \mathrm{g} / \mathrm{ml}$ which was considered to be relatively safe to use and much higher than the $\mathrm{LC}_{50}$ value of $142 \pm 68.2 \mu \mathrm{g} / \mathrm{ml}$ exhibited by the positive control [82]. Balogun and Ashafa [74] evaluated the cytotoxic activities of flavonoids isolated from the root extract of $D$. anomala using the brine shrimp lethality assay. The result of the lethality assay showed a potent cytotoxic effect of the flavonoids with $\mathrm{LC}_{50}$ value $0.510 \mathrm{mg} / \mathrm{ml}$. It is clear that detailed toxicity and cytotoxicity studies for such a widely used medicinal plant in tropical Africa are required.

\section{CONCLUSION}

Based on its wide use as herbal medicine in tropical Africa, D. anomala should be subjected to detailed ethnopharmacological evaluation aimed at elucidating its chemical, pharmacological, and toxicological properties. Such detailed ethnopharmacological research is required to substantiate medicinal claims associated with the species. For example, assessment of the antimycobacterial activities of the extracts of $D$. anomala are required as the species is widely used as herbal medicine against tuberculosis (TB) and other respiratory infections in Lesotho and South Africa [32,37,42]. Pulmonary TB is a highly communicable disease and represents a serious public health problem in the tropical and subtropical countries [83,84]. In the development of health care, herbal and pharmaceutical products, evaluation of the correlation between ethnomedicinal uses and phytochemistry and pharmacological properties is important. Based on current research results, it is difficult to correlate the ethnomedicinal uses of the species with the few phytochemical profiling and pharmacological evaluations that have been done so far. At the present moment, there is not yet enough systematic data regarding phytochemistry, pharmacological properties, and clinical research on D. anomala extracts and compounds. Detailed pharmacological studies should be carried out to provide some insight into the therapeutic potential of the species.

\section{ACKNOWLEDGMENTS}

Research reported in this publication was supported by the National Research Foundation (NRF) and Govan Mbeki Research and Development Centre (GMRDC), University of Fort Hare. The views and opinions expressed are not those of the NRF or GMRDC but of the author of the material published.

\section{AUTHOR' CONTRIBUTIONS}

I declare that this work was done by the author named in this article.

\section{CONFLICT OF INTEREST}

No conflict of interest is associated with this work. 


\section{REFERENCES}

1. Dzerefos CM, Witkowski ET. Density and potential utilization of medicinal grassland plants from Abe Bailey Nature Reserve, South Africa. Biod Cons 2001;10:1875-96.

2. Van Wyk BE. A review of African medicinal and aromatic plants. In: Neffati M, Najjaa H, MáthéÁ, editors. Medicinal and Aromatic Plants of the World: Africa. Vol. 3. Dordrecht: Springer; 2017. p. 19-60.

3. Van Wyk BE. The potential of South African plants in the development of new medicinal products. S Afr J Bot 2011;77:812-29.

4. Jacot-Guillarmod AJ. A medicine chest from the veld: Basotho materia medica. Veld F1 1981;5:113-5.

5. Moteetee A, Van Wyk BE. The medical ethnobotany of Lesotho: A review. Bothalia 2011;41:209-28.

6. Gelfand M, Mavi S, Drummond RB, Ndemera B. The traditional medicine practitioner in Zimbabwe: His principles of practice and pharmacopoeia. Gweru: Mambo Press; 1985.

7. Van Wyk BE, Gericke N. People's plants: A guide to useful plants of southern Africa. Pretoria: Briza Publications; 2007.

8. Watt JM, Breyer-Brandwijk MG. The medicinal and poisonous plants of southern and eastern Africa. Edinburgh: E and S Livingstone Ltd; 1962.

9. Morris B. Chewa medical botany: A study of herbalism in southern Malawi. Hamburg: Lit Verlag; 1996.

10. Meke GS, Mumba RF, Bwanali RJ, Williams VL. The trade and marketing of traditional medicines in southern and central Malawi. Int J Sustain Dev World Ecol 2017;24:73-87.

11. Williams VL, Balkwill K, Witkowski ET. A lexicon of plants traded in the Witwatersrand Umuthi shops. Bothalia 2001;31:71-98.

12. Monakisi CM. Knowledge and use of Traditional Medicinal Plants by the Setswana Speaking Community of Kimberley, Northern Cape of South Africa. MSc Dissertation. Cape Town: Stellenbosch University; 2007.

13. Talukdar S. Lesotho. In: Golding JS, editor. Southern African Plant Red Data Lists. Pretoria: Southern African Botanical Diversity Network Report No. 14, SABONET; 2002. p. 21-30.

14. Wild H. The compositae of the Flora Zambesiaca area. 3. Mutisieae. Kirkia 1972;8:189-92

15. Pope GV. Notes on Dicoma Cass. (Compositae). Kew Bull 1991;46:699-709.

16. Pope GV. Compositae. Flora Zambes 1992;6:37-8.

17. Onderstall J. Wild flower guide: Mpumalanga and northern Province. Nelspruit: Fishwicks the Printers; 1996.

18. Burrows JE, Willis CK. Plants of the Nyika Plateau: An Account of the Vegetation of the Nyika National Parks of Malawi and Zambia. Pretoria: Southern African Botanical Diversity Network Report No. 31 SABONET; 2005.

19. Setshogo MP. Preliminary Checklist of the Plants of Botswana. Pretoria: Southern African Botanical Diversity Network Report No. 37 SABONET; 2005.

20. Netnou N, Herman PP. Dicoma. In: Germishuizen G, Meyer NL, Steenkamp Y, Keith MA, editors. Plants of Southern Africa: An Annotated Checklist. Pretoria: Strelitzia 14: National Botanical Institute; 2006. p. 209-10.

21. Kirby G. Wild flowers of southeast Botswana. Cape Town: Struik Nature; 2013.

22. Mnegwane J, Koekemoer M. Dicoma anomala Sond. Pretoria: South African National Biodiversity Institute; 2007. Available from: http:// www.plantzafrica.com/plantcd/dicomanom.htm. [Last accessed on 2017 Jul 25]

23. Ortiz S, Rodriguez-Oubiña J. A new taxonomic interpretation of the Dicoma anomalacomplex (Mutisieae, Asteraceae). Nordic J Bot 1996;16:583-4.

24. Gelfand M. Medicine and Magic of the Mashona. Cape Town: Juta; 1956.

25. Mavi S. Medicinal Plants and their Uses in Zimbabwe. In: Norman H, Snyman I, Cohen M, editors. Indigenous Knowledge and Its Uses in Southern Africa. Cape Town: HSRC Press; 1996. p. 67-74.

26. Marekerah L. A Survey on the Biological Activities of Selected Plants used to Manage Diarrhoea and Cancer in Vumba, Zimbabwe. BSc Honours Dissertation. Gweru: Midlands State University; 2015.

27. Mwafongo E, Nordal I, Magombo Z, Stedje B. Ethnobotanical study of hyacinthaceae and non-hyacinthaceous geophytes in selected districts of Malawi. Ethnobot Res Appl 2010;8:75-93.

28. Mabona U, Viljoen A, Shikanga E, Marston A, Van Vuuren S. Antimicrobial activity of southern African medicinal plants with dermatological relevance: From an ethnopharmacological screening approach, to combination studies and the isolation of a bioactive compound. J Ethnopharmacol 2013;148:45-55

29. Maroyi A. Elephantorrhiza elephantina: Traditional uses, phytochemistry and pharmacology of an important medicinal plant species in southern Africa. Evid Based Complement Altern Med 2017;2017:6856154.

30. Madzinga M, Kritzinger Q, Lall N. Medicinal plants used in the treatment of superficial skin infections: From traditional medicine to herbal soap formulations. In: Lall N, editor. Medicinal Plants for Holistic Health and Well-Being. London: Academic Press; 2017. p. 256-76

31. Hutchings A, Scott AH, Lewis G, Cunningham AB. Zulu Medicinal Plants: An Inventory. Pietermaritzburg: University of Natal Press; 1996.

32. Maema LP, Mahlo SM, Potgieter MJ. Ethnomedicinal uses of indigenous plant species in Mogalakwena municipality of Waterberg District, Limpopo province South Africa. Int J Tradit Complem Med 2016;1:28-44.

33. Watt JM, Brandwijk MG. Suto (Basuto) medicines. Bantu Stud 1927;3:73-100.

34. Roberts M. Indigenous Healing Plants. Johannesburg: Southern Book Publishers; 1990.

35. Von Koenen E. Medicinal, Poisonous and Edible Plants in Namibia. Windhoek: Klaus Hess; 2001.

36. Semenya SS, Potgieter MJ, Tshisikhawe MP. Use, conservation and present availability status of ethno medicinal plants of Matebele village in the Limpopo province, South Africa. Afr J Biotechnol 2013;12:2392-405.

37. Kose LS, Moteetee A, Van Vuuren S. Ethnobotanical survey of medicinal plants used in the Maseru district of Lesotho. J Ethnopharmacol 2015; $170: 184-200$

38. Moteetee A, Kose LS. Medicinal plants used in Lesotho for treatment of reproductive and post reproductive problems. J Ethnopharmacol 2016;194:827-49.

39. Amusan OO, Sukati NA, Shongwe MS. Some phytomedicines from Shiselweni region of Swaziland. J Nat Remedies 2005;5:19-25.

40. Jacot-Guillarmod A. Flora of Lesotho. Lehre: J Cramer; 1971.

41. Mugomeri E, Chatanga P, Raditladi T, Makara M, Tarirai C. Ethnobotanical study and conservation status of local medicinal plants: Towards a repository and monograph of herbal medicines inLesotho. Afr J Tradit Complement Altern Med 2016;13:143-56.

42. Gerstner J. A preliminary checklist of Zulu names of plants with short notes. Bantu Stud 1939;13:49-64

43. Hedberg IF, Staugard F. Traditional Medicinal Plants: Traditional Medicine in Botswana. Gaborone: Ipelegeng Publishers; 1989.

44. Satyajit T, Andrew W, Matsabisa MG. Dicoma anomala Sond [Asteraceae]: Apossible resource of future antimalarial agents. Res Rev Res J Biol 2017;5:19-20.

45. Balogun FO, Tshabalala NT, Ashafa AO. Antidiabetic medicinal plants used by the Basotho tribe of eastern Free State: A review. J Diabetes Res 2016;2016:1-13.

46. Chinemana F, Drummond RB, Mavi S, De Zoysa I. Indigenous plant remedies in Zimbabwe. J Ethnopharmacol 1985;14:159-72.

47. Shale TL, Stirk WA, Van Staden J. Screening of medicinal plants used in Lesotho for anti-bacterial and anti-inflammatory activity. J Ethnopharmacol 1999;67:347-54

48. Setshogo MP, Mbereki CM. Floristic diversity and use of medicinal plants sold by street vendors in Gaborone, Botswana. Afr J Plant Sci Biotech 2011;5:69-74.

49. Semenya SS, Maroyi A. Medicinal plants used by the Bapedi traditional healers to treat diarrhoea in the Limpopo province, South Africa. J Ethnopharmacol 2012;144:395-401.

50. Bally PR. Native medicinal and poisonous plants of East Africa. Bull Miscell Inform 1937;1:10-26.

51. Varga CA, Veale DJ. Isihlambezo: Utilization patterns and potential health effects of pregnancy related traditional herbal medicine. Soc Sci Med 1997;44:911-24.

52. Panganai T, Shumba P. The African Pitocin- A midwife's Dilemma: The perception of women on the use of herbs in pregnancy and labour in Zimbabwe, Gweru. Pan Afr Medical J 2016;25:9.

53. Steenkamp V. Traditional herbal remedies used by South African women for gynaecological complaints. J Ethnopharmacol 2003;86:97-108.

54. Amusan OO, Dlamini PS, Msonthi JD, Makhubu LP. Some herbal remedies from Manzini region of Swaziland. J Ethnopharmacol 2002;79:109-12

55. Biegel HM. Rhodesian Wild Flowers. Harare: Thomas Meikle Series No. 4. Zimbabwe: Trustees of the National Museums and Monuments of Rhodesia; 1979.

56. Balogun FO, Ashafa AO. Aqueous root extracts of Dicoma anomala (Sond.) ameliorates against isoproterenol-induced myocardial infarction inWistar rats. Trop J Pharm Res 2016;15:1651-7. 
57. Moteetee A, Kose LS. A review of medicinal plants used by the Basotho for treatment of skin disorders: their phytochemical, antimicrobial, and anti-inflammatory potential. Afr J Tradit Complement Altern Med 2017;14:121-37.

58. Ndamba J, Nyazema N, Makaza N, Anderson C, Kaondera KC. Traditional herbal remedies used for the treatment of urinary schistosomiasis in Zimbabwe. J Ethnopharmacol 1994;42:125-32.

59. Kokwaro JO. Medicinal Plants of East Africa. Nairobi: East African Literature Bureau; 1976.

60. Chigora P, Masocha R, Mutenheri F. The role of indigenous medicinal knowledge (IMK) in the treatment of ailments in rural Zimbabwe: The case of Mutirikwi communal lands. J Sustain Dev Afr 2007;9:26-43.

61. Olivier DK, Van Wyk BE. Bitterness values for traditional tonic plants of southern Africa. J Ethnopharmacol 2013;147:676-9.

62. Olivier DK. The Ethnobotany and Chemistry of South African Tonic Plants. PhD Thesis. Johannesburg: University of Johannesburg; 2012.

63. Bohlmann F, Le Van N. New germacronolides from Dicoma anomala. Phytochem 1978;17:570-1.

64. Bohlmann F, Singh P, Jakupovic J. New germacronolides and other sesquitcrpene lactones from Dicoma species. Phytochem 1982;21:2029-33.

65. Zdero C, Bohlmann F. Sesquiterpene lactones from Dicoma species. Phytochem 1990;29:183-7.

66. Van der Merwe MM. Bioactive Sesquiterpenoids from Dicoma anomala subsp. gerradii. MSc Dissertation. Pietermaritzburg: University of KwaZulu-Natal; 2008.

67. Rademeyer M, Van Heerden FR, Van der Merwe MM. Dehydrobrachylaenolide: aneudesmane-type sesquiterpene lactone. Acta Cryst 2009;E65:196.

68. Becker JV, Van der Merwe MM, Van Brummelen AC, Pillay P, Crampton BG, Mmutlane EM, et al. In vitro anti-plasmodial activity of Dicoma anomala subsp. Gerrardii (Asteraceae): Identification of its main active constituent, structure-activity relationship studies and gene expression profiling. Malaria J 2011;10:295.

69. Bremer K. Asteraceae, Cladistics and Classification. Portland: Timber Press; 1994.

70. Mukanganyama S, Bezabih M, Robert M, Ngadjui BT, Kapche GF, Ngandeu F, et al. The evaluation of novel natural products as inhibitors of human glutathione transferase P1-1. J Enzyme Inhib Med Chem 2011;26:460-7.

71. Munodawafa T, Chagonda LS, Moyo SR. Antimicrobial and phytochemical screening of some Zimbabwean medicinal plants. J Biol Active Prod Nat 2013;3:323-30.

72. Mølgaard P, Nielsen SB, Rasmussen DE, Drummond RB, Makaza N,
Andreassen J. Anthelmintic screening of Zimbabwean plants traditionally used against schistosomiasis. J Ethnopharmacol 2001;74:257-64.

73. Balogun FO, Ashafa AOT. Aqueous roots extract of Dicomaanomala (Sond.) extenuates postprandial hyperglycaemia in vitro and its modulation against on the activities of carbohydrate-metabolizing enzymes in streptozotocin-induced diabetic Wistar Rats. S Afr J Bot 2017;112:102-111.

74. Balogun FO, Ashafa AO. Cytotoxic, kinetics of inhibition of carbohydrate-hydrolysing enzymes and oxidative stress mitigation by flavonoids roots extract of Dicoma anomala (Sond.). Asian Pac J Trop Med 2018;11:24-31.

75. Vlietinck AJ, Van Hoof L, Totte J, Lasure A, Van den Berghe D, Rwangabo PC, et al. Screening of hundred Rwandese medicinal plants for antimicrobial and antiviral properties. J Ethnopharrnacol 1995; 46:31-47.

76. Steenkamp V, Mathivha E, Gouws MC, Van Rensburg CE. Studies on antibacterial, antioxidant and fibroblast growth stimulation of wound healing remedies from South Africa. J Ethnopharmacol 2004;95:353-7.

77. Mabona U. Antimicrobial Activity of Southern African Medicinal Plants with Dermatological Relevance. MSc Dissertation. Johannesburg: Witwatersrand University; 2013.

78. Balogun F, Ashafa A. Comparative study on the antioxidant activity of Dicoma anomala and Gazania krebsiana used in Basotho traditional medicine. S Afr J Bot 2015;98:170.

79. Balogun F, Ashafa A. Antioxidant and hepatoprotective activities of Dicoma anomala Sond. aqueous root extract against carbon tetrachloride-induced liver damage in Wistar rats. J Trad Chinese Med 2016;36:504-13.

80. Tselanyane ML. The Isolation, Characterization and Antiplasmodial Activity of Two Novel Dimeric Sesquiterpenes from Dicoma anomala. PhD Thesis. Cape Town: University of Cape Town; 2006.

81. Asita AO, Heisi DH, Tjale T. Modulation of mutagen-induced genotoxicity by two Lesotho medicinal plants in Allium cepa L. Environ Nat Res 2015;5:37-55.

82. Munodawafa T, Moyo S, Chipurura B, Chagonda L. Brine shrimp lethality bioassay of some selected Zimbabwean traditional medicinal plants. Int J Phytopharmacol 2017;8:8-12.

83. Sawant DV, Desai MM, Patil RS, Pawar SH. Evolution of nanotech assisted PCR diagnosis of Mycobacterium tuberculosis and its assessment with conventional methods. Int J Pharm Pharm Sci 2018;10:133-7.

84. Illahi RK, Pramestutie HR, Desyana MS. The use of assistive counselling tool "lung TB care" to increase patient's knowledge level (a study in tuberculosis patients at Malang's primary health care centers). Int J Pharm Pharm Sci 2018;10:174-7. 